\title{
Media Pembelajaran Matematika Berbasis Edutainment dengan Pendekatan Metaphorical Thinking dengan Swish Max
}

\author{
Agustien Pranata Sukma ${ }^{1 *}$, Sri Purwanti Nasution', Bambang Sri Anggoro' ${ }^{1}$ \\ ${ }^{1}$ Universitas Islam Negeri Raden Intan Lampung, Jalan Endro Suratmin, Sukarame, Bandar \\ Lampung 35133, Indonesia \\ *Corresponding Author. E-mail: agustien.ps04@yahoo.com
}

Received : 30-11-2017; Revised : 24-01-2018; Accepted : 29-01-2018

\begin{abstract}
Abstrak
Penelitian ini bertujuan untuk menghasilkan media pembelajaran matematika berbasis edutainment berbantuan swish max melalui pendekatan metaphorical thinking terhadap pemahaman konsep matematis materi trigonometri. Metode penelitian ini yang digunakan tahapan pengembangan model Borg and Gall yang dimodifikasi oleh Sugiyono dengan tujuan untuk menciptakan produk tertentu dan menguji keefektifannya. Hasil penelitian menunjukkan bahwa pengembangan media pembelajaran memiliki kriteria sangat baik dengan rata-rata penilaian dari ahli materi sebesar 88,8\% dan media sebesar 85,7\%. Pada uji kemenarikan memiliki kriteria sangat baik pada kelompok kecil rata-rata presentase sebesar $88,4 \%$ dan uji coba lapangan $89,6 \%$. Media pembelajaran juga berpengaruh terhadap pemahaman konsep matematis peserta didik terbukti dari hasil test sebelum dan sesudah menunjukkan peningkatan indikator pemahaman konsep matematis dari kategori rendah menjadi tinggi. Kesimpulan dari penelitian ini adalah media pembelajaran yang dikembangkan memiliki kriteria sangat baik dan meningkatkan pemahaman konsep matematis peserta didik.
\end{abstract}

Kata kunci: Media Pembelajaran; Edutainment; SwishMax; Pendekatan Metaphorical Thingking; Pemahaman Konsep Matematis.

\begin{abstract}
This study aims to produce swed max edutainment based instructional media through metaphorical thinking approach to understanding mathematical concepts of trigonometric material. This research method used stages of Borg and Gall model development modified by Sugiyono with the aim to create a specific product and test its effectiveness. The results showed that the development of learning media has very good criteria with the average assessment of material experts of $88.8 \%$ and media by $85.7 \%$. In the attractiveness, the test has very good criteria in small groups average percentage of $88.4 \%$ and field trials $89.6 \%$. Learning media also affect the understanding of mathematical concepts of learners evident from the test results before and after showed improvement indicators of mathematical concepts from low to high category. The conclusion of this research is developed instructional media have very good criteria and improve understanding of the mathematical concept of learners.
\end{abstract}

Keywords: Learning Media; Edutainment; SwishMax; Metaphorical Thingking Approach; Understanding Mathematical Concepts

\section{PENDAHULUAN}

Pada era kemajuan ilmu pengetahuan teknologi, tentunya pendidikan harus mengikuti perkembangan zaman yang ada, dikarenakan pendidikan merupakan sarana untuk menuju kepada pertumbuhan dan perkembangan suatu bangsa. Pendidikan juga merupakan suatu investasi sumber daya manusia jangka panjang yang mempunyai nilai strategis bagi kelangsungan peradaban manusia di dunia ini (Yuliasari, 2017). Selain itu, menurut Bukunola dalam Widyawati pendidikan merupakan salah satu cara dalam mengenalkan pada 
manusia untuk memiliki pengetahuan dan sikap yang lebih baik (Widyawati, 2016). Maka dari itu, dapat disimpulkan bahwa tujuan dari kegiatan pendidikan adalah untuk membantu siswa agar dapat memaksimalkan potensi yang ada pada dirinya. Garapan pendidikan pada hakikatnya merupakan suatu sistem yang di laksanakan secara merata, menyeluruh, dan terpadu dalam melibatkan berbagai pihak termasuk lingkungan keluarga lingkungan masyarakat dan pemerintah baik secara sendiri-sendiri maupun secara bersama-sama (Supriadi, 2015). Namun dalam prosesnya, pendidikan tentu tidak terlepas dari peran seorang pendidik atau guru dalam suatu pembelajaran.

Guru dalam pendidikan merupakan salah satu figur penting yang bertanggung jawab dalam proses pembelajaran. Melalui aktivitas pembelajaran, guru dapat membedakan pembelajaran pasif, aktif dan interaktif. Guru dalam pembelajaran harus dapat mendorong siswa untuk membangun pengetahuannya sendiri, jika siswa hanya bertindak sebagai objek dalam pembelajaran, maka pembelajaran akan terkesan pasif. Siswa harus belajar dan mereproduksi materi yang ditransfer kepadanya (melalui guru atau sumber ilmu lain). Selain itu, penelitian lain telah membuktikan bahwa guru perlu memotivasi dan merangsang minat siswa (Gambari, Yusuf, \& Thomas, 2015; Serafin, 2016, p.). Maka dari itu, perlu adanya keterlibatan siswa dalam sebuah proses pembelajaran, yang pada akhirnya dapat meningkatkan keberhasilan siswa dan dapat membangun lingkungan belajar yang tepat. Diperjelas kembali oleh Karacop (Karacop, 2016) bahwa siswa harus aktif terlibat dalam proses belajar mengajar, agar dapat meningkatkan keberhasilan siswa untuk memahami materi pembelajaran dalam roses pendidikan. Salah satu faktor yang mempengaruhi berhasil atau tidaknya suatu proses pendidikan adalah proses pembelajaran yang berlangsung di kelas khususnya mata pelajaran matematika. Seiring dengan hal itu, melihat perkembangan sains, teknologi dan bidang keilmuan yang lain juga tidak terlepas dari peran matematika yang sangat besar.

Pembelajaran matematika dalam dunia pendidikan memiliki peranan penting bagi peserta didik dalam melatih kerjasama guna menghadapi berbagai masalah, berpikir secara logis, analitis, sitematis, kritis dan kreatif (Hernawan, Permasih, \& Dewi, 2012). Kualitas dari pembelajaran matematika sangat diperhatikan dalam usaha memperbaiki pendidikan di Indonesia. Hal ini diketahui dari jumlah jam pelajaran matematika di sekolah yang lebih banyak dibandingkan jam pelajaran lain (Abdullah, 2017; Dewi, Riastini, \& Pudjawan, 2017).

Salah satu tujuan pembelajaran matematika adalah agar peserta didik memiliki pemahaman konsep matematis yang baik, akan tetapi berdasarkan hasil analisis TIMSS tahun 2011 dengan menggunakan soal rutin dan non rutin menunjukkan bahwa peserta didik di Indonesia memiliki tingkat pemahaman konsep matematis yang rendah yaitu menduduki urutan 38 dari 42 negara dengan rata-rata skor 406 (Happy \& Widjajanti, 2014). Diduga proses kegiatan pembelajaran yang selalu berkutat dengan metode konvesional dan disuguhi dengan buku ajar menjadi penyebabnya. Kesuksesan dalam tujuan pembelajaran tidak terlepas dari perubahan dan pembaharuan dalam segala komponen pendidikan (Putra, 2016). Dalam hal ini penulis merasa dibutuhkan suatu tindakan oleh para pendidik dalam mengatasi hal ini dalam proses pembelajaran matematika. Salah satu tindakan itu adalah dalam penggunaan bahan ajar dan metode atau pendekatan dalam penyampaian materi.

Salah satu pendekatan yang dapat mempengaruhi suatu tingkat pemahaman 
Desimal, 1 (1), 2018 - 83

Agustien Pranata Sukma, Sri Purwanti Nasution, Bambang Sri Anggoro

konsep matematis pembelajar adalah Methaphorical Thinking. Seperti yang diungkapkan oleh Hidayat (Hidayat, 2017) bahwa Metaphorical thinking adalah proses berpikir dengan menggunakan metafora-metafora atau analogi-analogi agar mempermudah peserta didik dalam memahami dan menyerap sesuatu materi atau informasi tertentu. Berpikir metaforik dalam matematika digunakan untuk memperjelas jalan pikiran seseorang yang dihubungkan dengan aktivitas matematiknya. Konsep-konsep abstrak yang diorganisasikan melalui berpikir metaforik, dinyatakan dalam hal-hal kongkrit berdasarkan struktur dan caracara bernalar yang didasarkan sistem sensori-motor yang disebut dengan konseptual metafo (Hendriana, 2012). Maka dari itu dengan dengan pendekatan ini mampu mengatasi tingkat pemahaman konsep matematis siswa. Selain metode tersebut, penulis juga ingin memanfaatkan sebuah bahan ajar. Karena pada era jaman kemajuan tehcnologi seperti sekarang ini perlu pendidik lebih dituntut untuk lebih kreatif dan inovatif dalam menyampaikan pembelajaran didilam kelas. Kondisi ini didukung oleh pendapat yang disampaikan Sari $d k k$ (Sari, Farida, \& Putra, 2017) bahwa bahan ajar dalam pembelajaran mendapatkan respon yang baik dalam pembelajaran matematika. Bahan ajar menggunakan media komputer merupakan salah satu cara agar hasil belajar (pemahaman konsep) siswa menjadi lebih baik (Gusnidar, Netriwati, \& Putra, 2018); (Wulandari, Mujib, \& Putra, 2016); (Putra, 2015). Berdasarkan hal ini penulis tertarik melakukan sebuah penelitian dengan mengembangkan bahan ajar dalam pembelajaran matematika berbasis komputer.

Dalam

pengembangannya

penggunaan bahan ajar, penulis mencoba mengembangkan bahan ajar berbabasis Edutainment dengan bantuan Swish Max.
Edutainment merupakan suatu cara untuk agar proses pembelajaran menjadi menyenangkan sehingga peserta didik dengan mudah memahami materi pembelajaran (Minarti, Susilowati, \& Indriyanti, 2012). Hal ini didukung oleh Minarti $d k k$ (Minarti et al., 2012) bahwa pembelajaran dengan bahan ajar berbasis edutaiment adalah pembelajaran yang menyenangkan. Sedangkan swish max adalah aplikasi yang difungsikan untuk membuat animasi dalam waktu yang cepat (Umaisaroh, 2016). Menurut Inayati dkk (Inayati, Subroto, \& Supardi, 2012) bagi sudah paham menjalankan macromedia flash akan tersa lebih mudah dalam menggunakan alikasi swish max, karena program ini tidak telalu sulit dalam menjalankannya. Sehingga penulis tertarikmelakukan sebuah penelitian dengan mengembagkan bahan ajar Matematika Berbasis Edutainment Menggunakan Pendekatan Metaphorical Thinking dengan Swish Max guna meningkatkan Pemahaman Konsep Matematis siswa.

\section{METODE}

Jenis penelitian ini adalah Penelitian dan Pengembangan $(R \& D)$. Prosedur yang digunakan adalah 7 tahap dari 10 tahap model Borg and Gall. Tahapan itu adalah Potensi dan masalah, Pengumpulan data, Desain Produk, Validasi Desain, Revisi Desain, Uji Coba Produk, juga Revisi Produk. Tehnik pengumpulan data yang digunakan adalah Wawancara dan Angket respon.

Tabel 1. Skor Penilaian

\begin{tabular}{cc}
\hline Skor & Pilihan Jawaban Kelayakan \\
4 & Sangat baik \\
3 & Cukup baik \\
2 & Kurang baik \\
1 & Sangat tidak baik \\
\hline
\end{tabular}


Untuk pengkonversian skor kevalidan dan kelayakan media pembelajaran dapat dilihat pada Tabel 2.

\section{Tabel 2. Kriterian Kelayakan}

\begin{tabular}{lcc}
\hline No & Presentase & Kelayakan \\
1 & $0 \leq \mathrm{p} \leq 25$ & Sangat tidak baik \\
2 & $25<\mathrm{p} \leq 50$ & Kurang baik \\
3 & $50<\mathrm{p} \leq 75$ & Cukup baik \\
4 & $75<\mathrm{p} \leq 100$ & Sangat baik \\
\hline
\end{tabular}

selanjutnya persentase pencapaian dicari dengan menggunakan rumus sebagai berikut.

$$
P=\frac{\text { Jumlah skor }}{\text { Jumlah skor kriterium }} \times 100 \%
$$

Keterangan:

$P=$ persentase pencapaian.

Kemudian menyimpulkan hasil perhitungan berdasarkan katagori dengan melihat pada Tabel 3 .

\section{Tabel 3 Katagori Analisis Presentase}

\begin{tabular}{ccc}
\hline No & Presentase & Katagori \\
1 & $0 \leq \mathrm{p} \leq 25$ & Sangat rendah \\
2 & $25<\mathrm{p} \leq 50$ & Rendah \\
3 & $50<\mathrm{p} \leq 75$ & Sedang \\
4 & $75<\mathrm{p} \leq 100$ & Tinggi \\
\hline
\end{tabular}

\section{HASIL DAN PEMBAHASAN}

Media pembelajaran matematika berbasis edutainment berbantuan swish max melalui pendekatan metaphorical thinking merupakan hasil pengembangan yang dilaksanakan oleh peneliti. Berdasarkan prosedur yang telah dijelaskan maka hasil validasi desain diperoleh pada beberapa validator yaitu meliputi validator ahli media dan validator ahli materi matematika, yaitu dosen-dosen yang sesuai padakualifikasi yang telah ditentukan. Ujicoba produk dilaksanakandengan ujicoba kelompok kecil diujikan pada 10 peserta didik dan ujicoba kelompok besar diujikan pada 32 peserta didik SMA Negeri 5 Metro. Validasi dilaksanakan oleh ahli materi dan ahli media.

a. Validasi Ahli Materi

Hasil penilaian validasi ahli materi tahap 1 dan tahap 2 mengalami peningkatan. Diperoleh hasil bahwa media pembelajaran layak dan siap digunakan dengan kriteria "sangat baik", dapat dilihat pada Tabel 4 .

Tabel 4. Hasil Validasi Ahli Materi

\begin{tabular}{ccc}
\hline Presentase & Kriteria & Keterangan \\
$89 \%$ & Sangat baik & Tidak Revisi \\
\hline
\end{tabular}

b. Validasi Ahli Media

Hasil penilaian validasi ahli media tahap 1 mengalami peningkatan pada validasi ahli media tahap 2 , dapat dilihat pada Tabel 5 .

\section{Tabel 5. Hasil Validasi Ahli Media}

\begin{tabular}{ccc}
\hline Skor Rata-Rata & Kriteria & Keterangan \\
$86 \%$ & $\begin{array}{c}\text { Sangat } \\
\text { baik }\end{array}$ & Tidak Revisi \\
\hline
\end{tabular}

Hasil uji coba terkait kemenarikan media pembelajaran yang telah dikembangkan dilaksanakan melalui dua tahapan yaitu uji kelompok kecil dan besar. Hasil perhitungan kedua tahapan tersebut terangkum dan dapat dilihat juga pada Tabel 6 berikut. 
Desimal, 1 (1), 2018 - 85

Agustien Pranata Sukma, Sri Purwanti Nasution, Bambang Sri Anggoro

Tabel 6. Hasil Uji Kelompok Kecil

\begin{tabular}{cccc}
\hline Respon & Jumlah Skor & Presentase Kelayakan & Kriteria \\
1 & 47 & 90 & SM \\
2 & 46 & 88 & SM \\
3 & 48 & 92 & SM \\
4 & 39 & 75 & SM \\
5 & 47 & 90 & SM \\
6 & 46 & 88 & SM \\
7 & 47 & 90 & SM \\
8 & 45 & 87 & SM \\
9 & 48 & 92 & SM \\
10 & 48 & 92 & SM \\
Jumlah & $\mathbf{4 6 1}$ & $\mathbf{8 8 4}$ & $\bar{p}=\mathbf{8 8 , 4 \%}$ \\
\hline
\end{tabular}

Sedangkan pada uji skala besar dapat dilihat pada Tabel 7.

Tabel 7. Hasil Coba Kelompok Besar

\begin{tabular}{cccc}
\hline Respon & Jumlah Skor & Presentase Kelayakan & Kriteria \\
1 & 47 & 90 & SM \\
2 & 46 & 88 & $\mathrm{M}$ \\
3 & 48 & 92 & SM \\
4 & 46 & 88 & $\mathrm{M}$ \\
5 & 45 & 87 & $\mathrm{M}$ \\
6 & 47 & 90 & $\mathrm{M}$ \\
7 & 44 & 85 & $\mathrm{SM}$ \\
8 & 46 & 88 & $\mathrm{SM}$ \\
9 & 48 & 92 & $\mathrm{SM}$ \\
10 & 45 & 87 & $\mathrm{SM}$ \\
11 & 46 & 88 & $\mathrm{M}$ \\
12 & 48 & 92 & $\mathrm{M}$ \\
13 & 46 & 88 & $\mathrm{SM}$ \\
14 & 46 & 87 & $\mathrm{M}$ \\
15 & 45 & 87 & $\mathrm{M}$ \\
16 & 45 & 87 & $\mathrm{M}$ \\
17 & 45 & 94 & $\mathrm{M}$ \\
18 & 49 & 87 & SM \\
19 & 45 & 87 & $\mathrm{SM}$ \\
20 & 45 & 94 & $\mathrm{M}$ \\
21 & 49 & 94 & $\mathrm{SM}$ \\
22 & 49 & 88 & $\mathrm{SM}$ \\
23 & 46 & 90 & $\mathrm{SM}$ \\
24 & 47 & 94 & \\
25 & 49 & 92 & \\
26 & 48 & & $\mathrm{SM}$ \\
\hline & & & \\
\hline
\end{tabular}


Desimal, 1 (1), 2018 - 86

Agustien Pranata Sukma, Sri Purwanti Nasution, Bambang Sri Anggoro

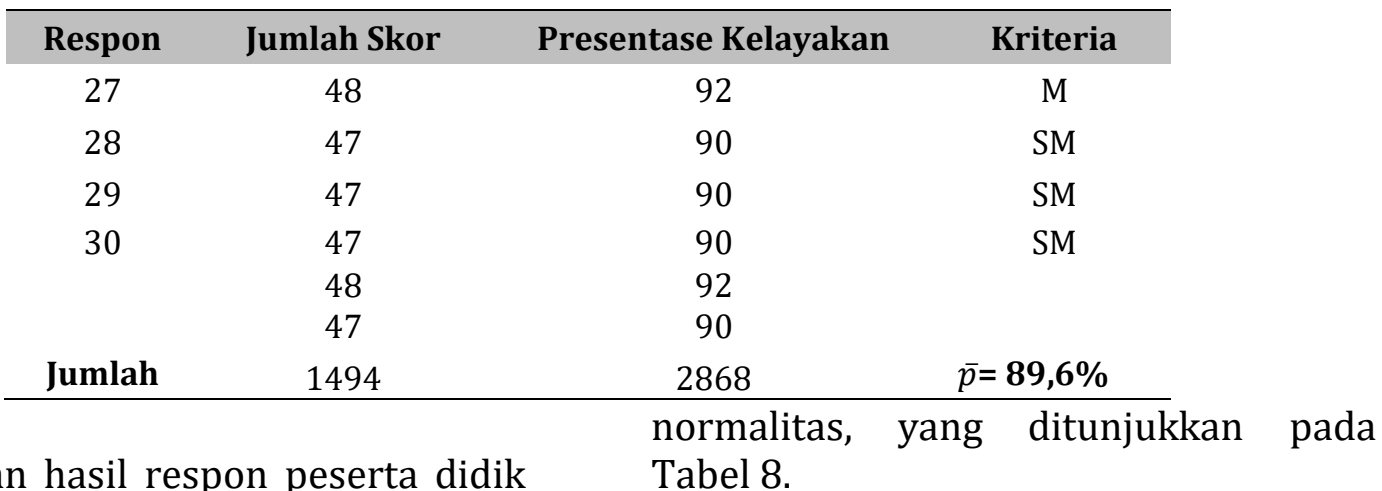

Berdasarkan hasil respon peserta didik diperoleh rata-rata persentase $88,4 \%$ dengan kriteria interpretasi yang dicapai yaitu "Sangat Baik" untuk uji coba kelompok kecil, sedangkan hasil uji coba kelompok besar memperoleh rata-rata persentase $89,6 \%$ dengan kriteria interpretasi yang dicapai yaitu "Sangat Baik".

Setelah melakukan uji coba kelompok kecil dan besar demi mengetahui kemenarikan media pembelajaran matematika berbasis edutainment berbantuan swish max melalui pendekatan metaphorical thinking terhadap pemahaman konsep matematis, maka disimpulkan produk tersebut dikatakan kemenarikannya sangat tinggi sehingga tidak dilakukan uji coba ulang. Sejalan dengan perolehan uji coba peserta didik hasil dari penilaian guru terhadap media pembelajaran yang dikembangkan menunjukkan diperoleh rata-rata persentase $85 \%$ dengan kriteria interpretasi yang dicapai yaitu "Sangat Baik". Selanjutnya media pembelajaran dapat dimanfaatkan sebagai salah satu media belajar bagi peserta didik dan guru di SMA pada materi trigonometri untuk kelas X.

Perolehan rata-rata skor postest pemahaman konsep matematis peserta didik pada uji coba terbatas dan lapangan lebih baik dibandingkan skor pretest, berdasarkan hasil paired t-test. Sebagai prasyarat paired t-test maka sebelumnya, peneliti melakukan uji
Tabel 8. Rangkuman Hasil Uji Normalitas Uji Terbatas Pretest

\begin{tabular}{lccc}
\hline \multirow{2}{*}{ Kelompok } & \multicolumn{2}{c}{ Pretest } & \multirow{2}{*}{ Kriteria } \\
Kecil & $\boldsymbol{p}_{\text {hitung }}$ & $\boldsymbol{p}_{\text {tabel }}$ & Normal \\
& 0,87 & 0,84 & \\
\hline
\end{tabular}

Tabel 9. Rangkuman Hasil Uji Normalitas Uji Terbatas Postest

\begin{tabular}{lccc}
\hline \multirow{2}{*}{ Kelompok } & \multicolumn{2}{c}{ Postest } & Kriteria \\
Kecil & $\boldsymbol{p}_{\text {hitung }}$ & $\boldsymbol{p}_{\text {tabel }}$ & Normal \\
& 0,86 & 0,84 & \\
\hline
\end{tabular}

Berdasarkan hasil uji normalitas data pemahaman konsep matematis uji terbatas yang terangkum dalam, terlihat nilai phitung lebih besar dari $p_{\text {tabel, }}$ sehingga dapat ditarik kesimpulanbahwa data uji coba kelompok kecil berasal dari populasi berdistribusi normal.

Tabel 10. Rangkuman Hasil Uji Normalitas Uji Lapangan Pretest

\begin{tabular}{|c|c|c|c|}
\hline \multirow[b]{2}{*}{ Kelompok } & \multicolumn{2}{|c|}{ Pretest } & \multirow[b]{2}{*}{ Kriteria } \\
\hline & $X_{\text {hitung }}^{2}$ & $X_{\text {tabel }}^{2}$ & \\
\hline Besar & 4,30 & 7,81 & Normal \\
\hline
\end{tabular}

Sedangkan hasil uji normalitas uji terbatas posttest dapat dilihat pada Tabel 11.

Tabel 11. Rangkuman Hasil Uji

Normalitas Uji Terbatas Postest

\begin{tabular}{|c|c|c|c|}
\hline \multirow[b]{2}{*}{ Kelompok } & \multicolumn{2}{|c|}{ Postest } & \multirow[b]{2}{*}{ Kriteria } \\
\hline & $X_{\text {hitung }}^{2}$ & $X_{\text {tabel }}^{2}$ & \\
\hline Besar & 6,77 & 7,81 & Besar \\
\hline
\end{tabular}


Desimal, 1 (1), 2018 - 87

Agustien Pranata Sukma, Sri Purwanti Nasution, Bambang Sri Anggoro

Berdasarkan hasil uji normalitas data pemahaman konsep matematis uji terbatas Pretest yang terangkum dalam, terlihat nilai phitung lebih besar dari $p_{\text {tabel, }}$ sehingga dapat ditarik kesimpulanbahwa data uji coba kelompok besar berasal dari populasi berdistribusi normal.

Data pemahaman konsep matematis peserta didik setelah memenuhi syarat normal, maka tahap selanjutnya adalah pengujian menggunakan paired t-test. Data pemahaman konsep matematis peserta didik menunjukkan, $t_{\text {hitung }}>t_{\text {tabel }}$, dengan taraf $\alpha=0,05$ dan $\mathrm{db}=31$ yang berarti rata-rata pemahaman konsep matematis peserta didik setelah penggunaan media pembelajaran lebih besar dari rata-rata sebelum penggunaan media pembelajaran sehingga dapat ditarik kesimpulanbahwa terdapat perbedaan yang signifikan antara pemahaman konsep matematis sebelum dan sesudah mengunakan media pembelajaran. dapat dilihat pada Tabel 12 .

Tabel 12. Rangkuman Hasil paired t-test Data Pemahaman Konsep Matematis

\begin{tabular}{lccll}
\hline \multirow{2}{*}{ Test } & \multicolumn{2}{c}{$\overline{\boldsymbol{x}}$} & \multirow{2}{*}{$\boldsymbol{t}_{\text {hitung }}$} & $\boldsymbol{t}_{\text {tabel }}$ \\
& Pretest & Postest & 6,17 & 2,26 \\
Terbatas & 55 & 71,1 & 6,17 & 2,04 \\
\hline
\end{tabular}

Berdasarkan semua ini berarti pembelajaran dengan menggunakan media pembelajaran berbasis edutaiment berbantuan SwishMax dengan pendekatan metaphorical thinking memiliki pengaruh terhadap pemahaman konsep matematis siswa. Penelitian ini sama dengan hasil penelitian sebelumnya bahwa pembelajaran berbasis edutaiment dengan menggunakan media pembelajaran dapat meningkatkan pemahaman konsep matematis peserta didik (Hernawati \& UNY, 2012; Lina, 2016; Minarti et al., 2012).

\section{SIMPULAN DAN SARAN}

Kesimpulan yang diperoleh dari penelitian dan pengembangan ini adalah media pembelajaran berbasis berbasis edutainment menggunakan pendekatan metaphorical thinking dikembangkan dengan Aplikasi Swish Max dengan menggunakan prosedur Borg and Gall. Serta media pembelajaran ini telah mencapai standar kelayakan dan memiliki pengaruh terhadap pemahaman konsep matematis berdasarkan angket para ahli dan siswa.

Berdasarkan kesimpulan, peneliti menyarankan agar segara digunakannya media pembelajaran berbasis edutainment disekolah guna meningkatkan pemahaman konsep matematis siswa.

\section{DAFTAR PUSTAKA}

Abdullah, S. S. (2017). Kesiapan mahasiswa LPTK swasta di Semarang menjadi guru matematika yang profesional. Pythagoras: Jurnal Pendidikan Matematika, 12(1), 87-97. https://doi.org/10.21831/pg.v12i1 .14051

Dewi, N. K. D. K., Riastini, P. N., \& Pudjawan, K. (2017). Pengaruh Model Pembelajaran Arias Terhadap Pemahaman Konsep Matematika Pada Siswa Kelas V SD Negeri 1 Candikusuma. MIMBAR PGSD Undiksha, 5(2).

Gambari, A. I., Yusuf, M. O., \& Thomas, D. A. (2015). Effects of ComputerAssisted STAD, LTM and ICI Cooperative Learning Strategies on Nigerian Secondary School Students' Achievement, Gender and Motivation in Physics. Malaysian Online Journal of Educational Sciences, 3(4), 11-26.

Gusnidar, G., Netriwati, N., \& Putra, F. G. (2018). Implementasi Strategi Pembelajaran Konflik Kognitif Berbantuan Software Wingeom 
Desimal, 1 (1), 2018 - 88

Agustien Pranata Sukma, Sri Purwanti Nasution, Bambang Sri Anggoro

Dalam Meningkatkan Kemampuan Pemecahan Masalah Matematis. Jurnal Edukasi Matematika Dan Sains, 5(2), 62-69.

Happy, N., \& Widjajanti, D. B. (2014). Keefektifan PBL ditinjau dari kemampuan berpikir kritis dan kreatif matematis, serta self-esteem siswa SMP. Jurnal Riset Pendidikan Matematika, 1(1), 48-57.

Hendriana, H. (2012). Pembelajaran matematika humanis dengan metaphorical thinking untuk meningkatkan kepercayaan diri siswa. Infinity Journal, 1(1), 90-103.

Hernawan, A. H., Permasih, H., \& Dewi, L. (2012). Pengembangan Bahan Ajar. Direktorat UPI, Bandung.

Hernawati, K., \& UNY, J. P. M. F. (2012). Pemanfaatan Sumber Belajar Internet Berbasis Edutainment dalam Pembelajaran Matematika Siswa Sekolah Dasar. In Prosiding Seminar Nasional Matematika UNY.

Hidayat, W. (2017). Adversity Quotient dan Penalaran Kreatif Matematis Siswa SMA dalam Pembelajaran Argument Driven Inquiry pada Materi Turunan Fungsi. KALAMATIKA Jurnal Pendidikan Matematika, 2(1), 15-28.

Inayati, I., Subroto, T., \& Supardi, K. I. (2012). Pembelajaran Visualisasi, Auditori, Kinestetik Menggunakan Media Swishmax Materi Larutan Elektrolit dan Non-Elektrolit. Chemistry in Education, 1(2).

Karacop, A. (2016). Effects of Student Teams-Achievement Divisions Cooperative Learning with Models on Students' Understanding of Electrochemical Cells. International Education Studies, 9(11), 104.

Lina, M. (2016). Pengaruh Metode Edutainment terhadap Peningkatan Hasil Belajar Siswa pada Materi Teknik-Teknik Dasar Memasak di SMK Negeri 2 Godean (PhD Thesis). UNY.
Minarti, I. B., Susilowati, S. M. E., \& Indriyanti, D. R. (2012). Pengembangan Perangkat Pembelajaran Ipa Terpadu Bervisi Sets Berbasis Edutainment pada Tema Pencernaan. Journal of Innovative Science Education, 1(2).

Putra, F. G. (2015). Eksperimentasi Model Pembelajaran Kooperatif Tipe Teams Games Tournament (TGT) Berbantuan Software Cabri 3d di Tinjau dari Kemampuan Koneksi Matematis Siswa. Al-Jabar: Jurnal Pendidikan Matematika, 6(2), 143-154.

Putra, F. G. (2016). Pengaruh Model Pembelajaran Reflektif dengan Pendekatan Matematika Realistik Bernuansa Keislaman terhadap Kemampuan Komunikasi Matematis. Al-Jabar: Jurnal Pendidikan Matematika, 7(2), 203210.

Sari, A. U., Farida, F., \& Putra, F. G. (2017). Pengembangan Media Pembelajaran Berbantuan Web dengan Pendekatan Etnomatematika Pada Pokok Bahasan Bangun Ruang Sisi Datar. Prosiding Seminar Nasional Matematika dan Pendidikan Matematika, 1(1), 209-214.

Serafin, C. (2016). The Reconceptualization of Cooperative Learning in an Inquiry-oriented Teaching. Procedia-Social and Behavioral Sciences, 217, 201-207.

Supriadi, N. (2015). Mengembangkan Kemampuan Koneksi Matematis Melalui Buku Ajar Elektronik Interaktif (BAEI) yang Terintegrasi Nilai-Nilai Keislaman. Al-Jabar: Jurnal Pendidikan Matematika, 6(1), 63-73.

Umaisaroh, U. (2016). Pengembangan Media Pembelajaran Fisika Berbasis Animasi Swishmax dengan Pendekatan Saintifik untuk Membantu Belajar Mandiri dalam 
Desimal, 1 (1), 2018 - 89

Agustien Pranata Sukma, Sri Purwanti Nasution, Bambang Sri Anggoro

Pemahaman Konsep Gerak

Melingkar. SKRIPSI Jurusan Fisika-

Fakultas MIPA UM.

Widyawati, S. (2016). Pengaruh Kemampuan Koneksi Matematis Siswa terhadap Prestasi Belajar Matematika Ditinjau dari Gaya Belajar pada Materi Bangun Ruang Sisi Datar Siswa Kelas IX SMP di Kota Metro. Iqra': Jurnal Kajian Ilmu Pendidikan, 1(1), 47-68.

Wulandari, P., Mujib, M., \& Putra, F. G. (2016). Pengaruh Model Pembelajaran Investigasi Kelompok berbantuan Perangkat Lunak Maple terhadap Kemampuan Pemecahan Masalah Matematis. Al-Jabar: Jurnal Pendidikan Matematika, 7(1), 101106.

Yuliasari, E. (2017). Eksperimentasi Model PBL dan Model GDL Terhadap Kemampuan Pemecahan Masalah Matematis Ditinjau dari Kemandirian Belajar. JIPM (Jurnal Ilmiah Pendidikan Matematika), 6(1), 1-10. 